\title{
ТАБЛЕТКОВІ СУМІШІ, ЩО МІСТЯТЬ ІММОБІЛІЗОВАНИЙ ЛІЗОЦИМ I КВЕРЦЕТИН: ОТРИМАННЯ, ВЛАСТИВОСТІ
}

Вступ. Лізоцим (КФ 3.2.1.17), що має антибактеріальну, протизапальну, імуномодулюючу дії, все частіше використовують у медицині в різних лікарських фрормах (таблетки, ранові покриття, капсули, гелі та ін.). Таблетки є зручною лікарською фрормою для застосування лізоциму в поєднанні з іншими біологічно активними речовинами. Цілеспрямована стабілізація ензиму іммобілізацією в полімерні матриці визначає актуальність розробки таблеткової фрорми складних композицій лізоциму і кверцетину.

Мета дослідження - розробка таблеткових сумішей комплексного препарату іммобілізованого лізоциму і кверцетину, кількісне визначення та вивчення властивостей діючих речовин.

Методи дослідження. Активність лізоциму визначали бактеріолітичним методом. Вміст білка контролювали методом Лоурі-Хартрі, кверцетину - з використанням хлориду цирконію.

Результати й обговорення. На основі раніше отриманих даних про взаємодію лізоциму з полімерними носіями різного походження та структури для розробки таблеткових сумішей з лізоцимом і кверцетином як полімерні носії було обрано полі-N-вінілпіролідон, натрієву сіль карбоксиметилцелюлози та желатин. Порівняльний аналіз фрізико-хімічних властивостей іммобілізованого в полімери лізоциму показав перспективність використання желатину як матриці, що сприяє розширенню рН-профрілю активності ензиму в ділянці кислих та лужних значень рН, стабільності в кислому середовищі. Для приготування лізоциму і кверцетиновмісних сумішей було обрано наповнювачі, розпушувачі, ароматизатори і метод вологої грануляції. Показано повне збереження активності лізоциму і вмісту кверцетину в отриманих гранулах.

Висновки. Розроблено таблеткові суміші з лізоцимом і кверцетином із використанням полімерних носіїв різного походження та структури. Аналіз біохімічних і фрізико-хімічних властивостей іммобілізованого лізоциму показав перспективність використання желатину як матриці. Іммобілізація сприяє розширенню рН-профрілю активності ензиму як у ділянці кислих та лужних значень рН, так і в кислому середовищі.

КЛЮЧОВІ СЛОВА: лізоцим; кверцетин; іммобілізація; полімери; таблеткові суміші.

ВСТУП. На даний час, у зв'язку зі зростанням резистентності мікроорганізмів до антибіотиків, увага дослідників спрямована на використання для лікування ряду захворювань (стоматологічних (стоматитів, гінгівіту, пародонтиту тощо), ЛОР (фрарингіту, тонзиліту, ларингіту) та ін.) природних антибактеріальних агентів. Ензим лізоцим (КФ 3.2.1.17), що має антибактеріальну, протизапальну, імуномодулюючу, аналгетичну дії, все частіше застосовують у медицині у вигляді різних лікарських фрорм: таблеток, ранових покриттів, капсул, гелів та ін. [1, 2]. Перспективною лікарською формою лізоциму для місцевого використання в комплексі з іншими біологічно активними речовинами є таблетки. В Україні таблеткові форми представлені препаратами (c) І. І. Романовська, С. С. Декіна, О. В. Севастьянов, €. О. Рогожа, 2017.
“Лізак" (“Фармак”, Україна), "Гексаліз" (“Lab. Bouchara-Recordati”, Франція) і “Лісобакт" ("Bosnalijek", Боснія і Герцеговина). Застосування технології іммобілізації з використанням полімерних матриць для цілеспрямованої стабілізації ензиму визначає актуальність досліджень 3 метою отримання комплексних композицій лізоциму і кверцетину, придатних для дослідження та подальшого виготовлення таблетки. Додаткове введення в суміші діючої речовини - кверцетину збільшує можливість розширення фрармакологічної дії препарату [3, 4], оскільки кверцетин має протизапальну, антиоксидантну, капіляропротекторну, противірусну, антитромботичну дії.

Мета дослідження - розробка таблеткових сумішей комплексного препарату іммобілізованого лізоциму і кверцетину, кількісне визначення та вивчення властивостей діючих речовин. 
МЕТОДИ ДОСЛІДЖЕННЯ. У роботі використовували лізоцим яєчного білка (КФ 3.2.1.17) (M.м. 14,4 кДа, 40000 од./мг), клітини Micrococcus lysodeikticus 2665 ("Sigma-Aldrich", Німеччина), кверцетин (“Sigma-Aldrich", Німеччина), натрієву сіль карбоксиметилцелюлози (Na-KМЦ) (М.м. 125 кДа, FMC Biopolymer, Ireland), полі-N-вінілпіролідон (Taian Health Chemical Co., Ltd., Китай), крохмаль (Taian Health Chemical Co., Ltd., Китай), желатин (РВІ, Бельгія). Активність лізоциму визначали бактеріолітичним методом (субстрат клітини Micrococcus lysodeikticus 2665) [1]. 3a одиницю активності ензиму брали таку його кількість, що знижує оптичну густину суспензії клітин на 0,001 за 1 хв. Вміст білка контролювали методом Лоурі-Хартрі [5], кверцетину - за допомогою хлориду цирконію [6].

Для виготовлення таблеткових сумішей компоненти (хлоргексидину біглюконат, етилендіамінтетраацетат натрію, лактозу, кальцію тригідрат, маніт, ароматизатор, сахарозу, натрієву сіль карбоксиметилцелюлози, повідон К-17, желатин, кальцію стеарат), залежно від складу суміші, ретельно розтирали в ступці до їх подрібнення в тонкий порошок. Далі всі компоненти зволожували розчином полімеру (ПВП, Na-КМЦ або желатину). Гранулювання здійснювали шляхом протирання одержаної маси через пробивне сито 3 нержавіючої сталі з діаметром отворів 1,5 мм. Отримані гранули розсипали тонким шаром на піддонах і підсушували на повітрі при кімнатній температурі до залишкової вологостів гранулах, що не перевищує $2 \%$. Після висушування гранулят зважували, визначали вміст компонентів і зберігали герметично упакованим при температурі $4^{\circ} \mathrm{C}$.

РЕЗУЛЬТАТИ Й ОБГОВОРЕННЯ. ПрИ СТВОренні таблеткових сумішей з діючими речовинами лізоцимом і кверцетином особливого значення надавали вибору полімерних носіїв для стабілізації ензиму (зв'язувальних компонентів суміші), дослідженню фрізико-хімічних властивостей іммобілізованого ензиму, складу допоміжних речовин, вибору методу таблетування, збереженню активності/вмісту діючих речовин композиції. Дози лізоциму і кверцетину було визначе- но, виходячи з рекомендованих для медичного застосування з лікувальною та профілактичною метою - 50 і 10 мг в 1 г таблеткової суміші відповідно [2]. Для підсилення антимікробної дії лізоциму запропоновано ввести до складу сумішей з ПВП та Na-КМЦ динатрієву сіль етилендіамінтетраоцтової кислоти (ЕДТА) і хлоргексидину біглюконат (ХГБ), що має бактерицидну дію (мольні відношення лізоцим:ЕДТА:ХГБ 1:0,012:0,09). Раніше було показано, що додавання ХГБ сприяє розширенню антимікробної дії ензиму щодо грамнегативних, грампозитивних бактерій і дріжджоподібних грибків; введення комплексону більшою мірою сприяє розширенню антимікробної дії лізоциму стосовно грамнегативних бактерій E. coli та дріжджоподібних грибків Candida albicans [7]. Основними критеріями при виборі полімерів для стабілізації лізоциму (ПВП, Na-КМЦ і желатину) були відсутність токсичності, біодеградація, застосування у фрармацевтичній промисловості.

Взаємодію лізоциму з даними полімерами підтверджено за допомогою реологічних, оптичних і мас-спектрометричних методів [8]. Зміна в'язкості розчинів полімерів при додаванні лізоциму, використання УФ-спектроскопії, люмінесценції, МАЛДІ свідчать про утворення комплексу білок - полімер, збереження природної конформації ензиму [3]. Міцність зв'язування білка з носієм зумовлена природою взаємодіючих речовин, сприяє пролонгуванню дії ензиму. Показано повне збереження активності лізоциму в результаті взаємодії з ПВП, Na-КМЦ і желатином (табл. 1).

Слід відмітити, що термооптимум ензиму в усіх випадках не змінився, проте спостерігали розширення $\mathrm{pH}$-оптимуму лізоциму, більш значне при використанні желатину як носія, що збільшує можливість застосовувати лізоцим у середовищах різної кислотності. На рисунку 1 наочно продемонстровано розширення $\mathrm{pH}$-профрілю активності стабілізованого желатином лізоциму в ділянці кислих і лужних значень. Так, активність іммобілізованого лізоциму при значеннях рН 3,0 та 8,0 зросла більш ніж на 15 і 30 \% відповідно порівняно з вільним, що можна пояснити стабілізувальним впливом матриці,

Таблиця 1 - Вплив полімерів на біохімічні та фрізико-хімічні властивості лізоциму

\begin{tabular}{|l|c|c|c|c|}
\hline \multicolumn{1}{|c|}{ Властивість } & ЛІ3 & ЛІ3+ПВП & ЛІ3+Na-КМЦ & ЛІ3+желатин \\
\hline $\begin{array}{l}\text { Бактеріолітична активність*, } \\
\text { од./мг }(\mathrm{M} \pm \mathrm{m})\end{array}$ & $20000 \pm 1000$ & $19000 \pm 870$ & $18500 \pm 850$ & $19300 \pm 790$ \\
\hline рН-оптимум & 6,5 & \multicolumn{2}{|c|}{$6,5-7,50$} & $5,0-8,0$ \\
\hline Термооптимум, ${ }^{\circ} \mathrm{C}$ & 55 & \multicolumn{3}{|c|}{55} \\
\hline
\end{tabular}

Примітки:

1. * $-p<0,05$ при $n=3$.

2. лІз - лізоцим. 


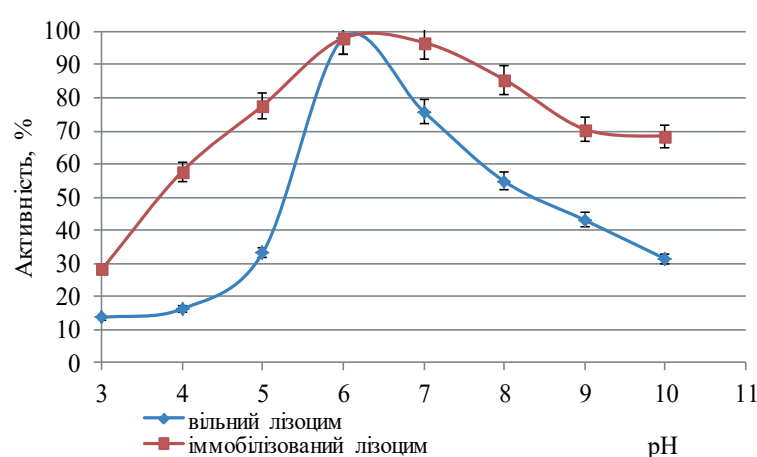

Рис. 1. Залежність активності вільного й іммобілізованого в желатин лізоциму від $\mathrm{pH}$ інкубаційного середовища $\left(\mathrm{T}=37^{\circ} \mathrm{C}\right)$. створенням сприятливішого мікрооточення ензиму. При дослідженні рН-стабільності ензиму за умов, наближених до ацидозу (рис. 2), активність як вільного, так і іммобілізованого лізоциму з часом знижувалась, однак останній проявляв вищу активність (<20 \%) через 30, 60 і 120 хв експерименту

Таким чином, будучи перспективною матрицею для створення іммобілізованих фоом лізоциму [8, 9], желатин "захищає” його від негативного впливу кислих і лужних значень рН. Крім того, желатин, маючи значну кількість доступних пептидних зв'язків, є протектором лізоциму відносно агресивної дії протеаз організму людини. Він також є перспективним джерелом цінних для організму людини білка й амінокислот, у т. ч. незамінних: глутамінової кислоти-9,71\%; проліну -

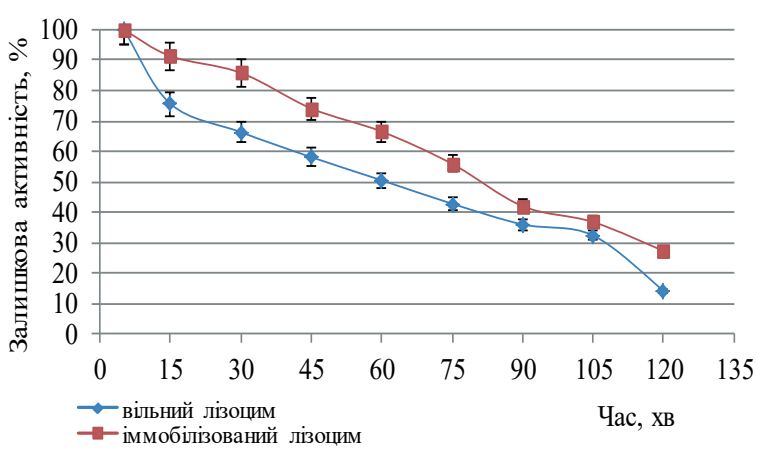

Рис. 2. Стабільність вільного й іммобілізованого в желатин лізоциму ( $\left.\mathrm{pH} 5,5 ; \mathrm{T}=37^{\circ} \mathrm{C}\right)$.

13,63 \%; аспарагіну - 5,7 \%; лейцину - 3,66 \%; аргініну - 7,67\%; гліцину - $23 \%$; аланіну 9,37\%; гідроксипроліну - 11,76 \%; інших $15,51 \%[10]$.

Для виготовлення таблеткових сумішей, крім описаних діючих, зв'язувальних і тих, що стабілізують активність лізоциму, полімерів, використано наповнювачі, дезінтегранти, ароматизатори. Вибір складу допоміжних речовин був зумовлений їх нешкідливістю, безпечністю, технологічними вимогами.

3 огляду на суттєві відмінності в розмірах, соормі, поверхні частинок, неоднорідність компонентів отриманих таблеткових сумішей, необхідність одержання іммобілізованої фрорми лізоциму, обрано технологію вологого гранулювання, що забезпечує отримання однорідних гранул 3

Таблиця 2 - Склад таблеткових сумішей з лізоцимом і кверцетином (у розрахунку на одну таблетку)

\begin{tabular}{|c|c|c|c|c|c|c|c|c|}
\hline \multirow{2}{*}{ № } & \multirow{2}{*}{ Компонент } & \multicolumn{7}{|c|}{ Кількість компонентів в одній таблетці, мг } \\
\hline & & 1 & 2 & 3 & 4 & 5 & 6 & 7 \\
\hline \multicolumn{9}{|c|}{ Діючі речовини } \\
\hline 1 & Лізоцим & 10,0 & 10,0 & 10,0 & 10,0 & 10,0 & 10,0 & 15,0 \\
\hline 2 & Кверцетин & 2,0 & 2,0 & 2,0 & 2,0 & 2,0 & 2,00 & 5,0 \\
\hline 3 & Хлоргексидину & 2,0 & 2,0 & 2,0 & 2,0 & 2,0 & 2,0 & 5,0 \\
\hline 4 & $\mathrm{Na}_{2}$ ЕДТА & 3,0 & 3,0 & 3,0 & 3,0 & 3,0 & 3,0 & - \\
\hline \multicolumn{9}{|c|}{ Наповнювачі } \\
\hline 5 & Лактоза & 114,9 & 154,5 & 149,5 & 155,5 & 160,0 & 164,1 & - \\
\hline 6 & Кальцію цитрат & - & - & - & - & - & - & 360,0 \\
\hline \multicolumn{9}{|c|}{ Дезінтегранти } \\
\hline 7 & Маніт & 17,9 & 17,9 & 17,9 & 17,9 & 17,9 & 17,9 & - \\
\hline \multicolumn{9}{|c|}{ Смакові добавки } \\
\hline 8 & $\begin{array}{l}\text { Ароматизатор } \\
\text { "Лимон" }\end{array}$ & 0,6 & 0,6 & 0,6 & 0,6 & 0,6 & 0,6 & 1,2 \\
\hline 9 & Сахароза & - & - & - & - & - & - & 3,0 \\
\hline \multicolumn{9}{|c|}{ Зв'язувальні речовини } \\
\hline 10 & Na-KMЦ & - & - & 15 & 9 & 4,5 & 0,4 & - \\
\hline 11 & Повідон К-17* & 50 & 10 & - & - & - & - & - \\
\hline 12 & Желатин* & - & - & - & - & - & - & 210,0 \\
\hline \multicolumn{9}{|c|}{ Змащувальні речовини } \\
\hline 13 & Кальцію стеарат & - & - & - & - & - & - & 0,8 \\
\hline & Усього & 200,0 & 200,0 & 200,0 & 200,0 & 200.0 & 200,0 & 600,0 \\
\hline
\end{tabular}

Примітка. * - як зв'язувальну речовину застосовували ПВП (5 \% водний розчин для сумішей № 1, 2), Na-КМЦ (0,1, 1,5, 3,0 \% водні розчини для сумішей № 3,4; № 5; № 6 відповідно) або желатин (суміш № 7). 
Таблица 3 - Активність лізоциму і вміст кверцетину в таблеткових сумішах

\begin{tabular}{|c|c|c|c|c|}
\hline \multirow{2}{*}{$\begin{array}{c}\text { № } \\
3 / \Pi^{\star}\end{array}$} & \multicolumn{2}{|c|}{$\begin{array}{c}\text { Бактеріолітична активність } \\
\text { лізоциму }\end{array}$} & \multicolumn{2}{|l|}{ Вміст кверцетину } \\
\hline & од./мг (M $\pm \mathrm{m})$ & \% від вихідної & мкг у 5 мг грануляту (M $\pm m)$ & \% від внесеного \\
\hline 1 & $19320 \pm 1160$ & 96,60 & $45,67 \pm 2,28$ & 97,55 \\
\hline 2 & $19253 \pm 1116$ & 96,27 & $45,14 \pm 2,26$ & 94,6 \\
\hline 3 & $17365 \pm 868$ & 86,82 & не визначено через нерозчинність гранул & - \\
\hline 4 & $18145 \pm 1160$ & 90,73 & не визначено через нерозчинність гранул & - \\
\hline 5 & $19160 \pm 958$ & 95,80 & $46,26 \pm 2,31$ & 96,90 \\
\hline 6 & $19227 \pm 961$ & 96,14 & $45,58 \pm 2,28$ & 95,48 \\
\hline 7 & $19290 \pm 975$ & 99,85 & $44,95 \pm 2,0$ & 98,42 \\
\hline
\end{tabular}

Примітка. * - № суміші при n=3.

рівномірно розподіленими діючими компонентами.

У таблиці 2 наведено якісний та кількісний склад розроблених таблеткових сумішей з лізоцимом і кверцетином, виходячи з розрахунку, що маса однієї таблетки буде становити 200,0 мг (суміші № 1-6) або 600,0 мг (суміш № 7).

У результаті отримано гранули жовтого кольору без видимих сторонніх включень (d=1,5 мм). У композиціях визначали активність лізоциму і вміст кверцетину (табл. 3).

Одержані результати свідчать про високий рівень збереження активності лізоциму і вмісту кверцетину в сумішах № 1, 2, 5, 6, 7, перспективних для подальших біофрармацевтичних досліджень.

ВИСНОВКИ. 1. На підставі раніше отриманих даних про взаємодію лізоциму з полімерними носіями різного походження та структури для розробки таблеткових сумішей з лізоцимом і кверцетином обрано полі-N-вінілпіролідон, натрієву сіль карбоксиметилцелюлози, желатин, які застосовують у фрармацевтичній промисловості.

2. Порівняльний аналіз фрізико-хімічних властивостей іммобілізованого в полімери лізоциму показав перспективність використання желатину як носія, що сприяє розширенню рН-просрілю активності ензиму в ділянці кислих і лужних значень рН, стабільності в кислому середовищі та має власні позитивні властивості (джерело цінних амінокислот і пептидів, протекторна дія).

3. Для виготовлення таблеткових сумішей обрано наповнювачі, дезінтегранти, ароматизатори і метод вологого гранулювання. Показано повне збереження активності лізоциму і вмісту кверцетину в отриманих гранулятах.

\section{СПИСОК ЛІТЕРАТУРИ}

1. Левицкий А. П. Лизоцим вместо антибиотиков / А. П. Левицкий. - Одесса: Изд-во КП ОГТ, 2005. - 74 с.

2. Бурбелло А. Т. Современные лекарственные средства : клинико-фрармакологический справочник практического врача / А. Т. Бурбелло, А. В. Шабров. М. : ОлмаМедиаГрупп/Просвещение, 2010. - 800 с.

3. Мукоадгезивний гель з іммобілізованими лізоцимом і кверцетином / I. І. Романовська, А. П. Левицький, С. С. Декіна, А. М. Овсепян // Мікробіологія і біотехнологія. - 2015. - № 3. - С. 30-39.

4. Chirumbolo $\mathrm{S}$. The role of quercetin, flavonols and flavones in modulating inflammatory cell function / S. Chirumbolo // Inflamm. Allergy Drug Targets. -2010. - 9 (4). P. 263-285.

5. Hartree E. F. Determination of protein: a modification of the Lowry method, that gives a linear photometric response / E. F. Hartree // Analytical Biochemistry. 1972. - 48, № 2. - P. 422-427.
6. Ogura H. Quantitative analysis of flavonoids / H. Ogura, Y. Shikiba, Y. Yamazaki // J. of Pharmaceutical Sciences. - 1968. - 57, № 4. - P. 705-706.

7. Дослідження чутливості мікроорганізмів до комбінацій лізоциму з лікарськими речовинами / І. І. Романовська, С. С. Декіна, І. Й. Псахіс, Б. Й. Псахіс // Мед. та клініч. хімія. - 2016. - 18, № 2 (67). C. $68-70$

8. Декина С. С. Влияние полимеров на процессы ассоциации молекул лизоцима / С. С. Декина, И. И. Романовская, Т. Ю. Громовой // Biopolymers and cells. - 2011. - 27, № 6. - P. 442-445.

9. Carboxymethyl cellulose mucoadhesive films with lysozyme: Development and characterization / S. Dekina, I. Romanovska, A. Ovsepyan [et al.] // Carbohydrate Polymers. - 2016. - 147. - P. 208-215

10. Вейс А. Макромолекулярная химия желатина / А. Вейс. - М. : Пищевая промышленность, 1971. 479 c. 


\section{REFERENCES}

1. Levytskyi, A.P. (2005). Lizotsym vmesto antibiotikov [Lysozyme instead antibiotics]. Odessa: Izd-vo KP OGT [in Russian].

2. Burbello, A.T., \& Shabrov, A.V. Sovremennye lekarstvennye sredstva: Kliniko-farmakologicheskiy spravochnik prakticheskogo vracha [Modern medicines: Clinical and pharmacological reference book of a practical doctor]. Moscow: OlmaMediaGrupp/Prosveshchenie [in Russian].

3. Romanovska, I.I., Levytskyi, A.P., Dekina, S.S., \& Ovsepian, A.M. (2015). Mukoadhezyvnyi hel z immobilizovanymy lizotsymom i kvertsetinom [Mucoadhesive gel with immobilized lysozyme and quercetin]. Mikrobiolohiia i biotekhnolohiia - Microbiology and Biotechnology, (3), 30-39 [in Ukrainian].

4. Chirumbolo, S. (2010). The role of quercetin, flavonols and flavones in modulating inflammatory cell function. Inflamm. Allergy Drug Targets, 9 (4), 263-285.

5. Hartree, E.F. (1972). Determination of protein: a modification of the Lowry method, that gives a linear photometric response. Analytical Biochemistry, 48 (2), 422-427.
6. Ogura, H., Shikiba, Y., \& Yamazaki, Y. (1968). Quantitative analysis of flavonoids. J. of Pharmaceutical Sciences, 57 (4), 705-706.

7. Romanovska, I.I., Dekina, S.S., Psakhis, I.Y., \& Psakhis, B.Y. (2016). Doslidzhennia chutlivosti mikroorhanizmiv do kombinatsiy lizotsimu z likarskymy rechovynamy [Investigation of the sensitivity of microorganisms to lysozyme combination with drugs]. Medychna khimiia Medical Chemistry, 18 (2), 68-70 [in Ukrainian].

8. Dekina, S.S., Romanovskaya, I.I., \& Gromovoy, T.Yu. Vliyaniye polimerov na protsessy assotsiatsii molekul lizotsima [The influence of polymers on the processes of association of lysozyme molecules]. Biopolymers and Cells, 27 (6), 442-445 [in Russian].

9. Dekina, S., Romanovska, I., Ovsepyan, A., Tkach, V., \& Muratov, E. (2016). Gelatin/ carboxymethyl cellulose mucoadhesive films with lysozyme: Development and characterization. Carbohydrate Polymers, 147, 208-215.

10. Veys, A. (1971). Makromolekulyarnaya khimiya zhelatina [Macromolecular chemistry of gelatine]. Moscow: Izdatelstvo "Pishchevaya promyshlennost" [in Russian].

И. И. Романовская ${ }^{1}$, С. С. Декина ${ }^{1}$, О. В. Севастьянов ${ }^{1}$, Е. А. Рогожа ${ }^{2}$ ФИЗИКО-ХИМИЧЕСКИЙ ИНСТИТУТ ИМЕНИ А. В. БОГАТСКОГО НАН УКРАИНЫ ${ }^{1}$, ОДЕССА ОДЕССКИЙ НАЦИОНАЛЬНЫЙ ПОЛИТЕХНИЧЕСКИЙ УНИВЕРСИТЕТ

\section{ТАБЛЕТОЧНЫЕ СМЕСИ, СОДЕРЖАЩИЕ ИММОБИЛИЗОВАННЫЙ ЛИЗОЦИМ И КВЕРЦЕТИН: ПОЛУЧЕНИЕ, СВОЙСТВА}

\section{Резюме}

Вступление. Лизоцим (КФ 3.2.1.17), обладающий антибактериальным, противовоспалительным, иммуномодулирующим действиями, все чаще используют в медицине в различных лекарственных фрормах (таблетки, раневые покрытия, капсулы, гели и пр.). Таблетки являются удобной лекарственной фрормой для применения лизоцима в сочетании с другими биологически активными веществами. Целенаправленная стабилизация энзима иммобилизацией в полимерные матрицы определяет актуальность разработки таблеточной фрормы сложных композиций лизоцима и кверцетина.

Цель исследования - разработка таблеточных смесей комплексного препарата иммобилизованного лизоцима и кверцетина, количественное определение и изучение свойств действующих веществ.

Методы исследования. Активность лизоцима определяли бактериолитическим методом. Содержание белка контролировали методом Лоури-Хартри, кверцетина - с использованием хлорида циркония.

Результаты и обсуждение. На основе ранее полученных данных о взаимодействии лизоцима с полимерными носителями различного происхождения и структуры для разработки таблеточных смесей с лизоцимом и кверцетином в качестве полимерных носителей были выбраны поли-N-винилпирролидон, натриевая соль карбоксиметилцеллюлозы и желатин. Сравнительный анализ фризико-химических свойств иммобилизованного в полимеры лизоцима показал перспективность использования желатина в качестве матрицы, что способствует расширению $\mathrm{pH}$-профиля активности энзима в области кислых и щелочных значений рН, стабильности в кислой среде. Для приготовления лизоцима и кверцетинсодержащих таблеточных смесей были выбраны наполнители, разрыхлители, ароматизаторы и метод влажной грануляции. Показано полное сохранение активности лизоцима и содержания кверцетина в полученных гранулах.

Выводы. Разработаны таблеточные смеси с лизоцимом и кверцетином с использованием полимерных носителей различного происхождения и структуры. Анализ биохимических и фризико-химических 
свойств иммобилизованного лизоцима показал перспективность использования желатина в качестве матрицы. Иммобилизация способствует расширению рН-профиля активности энзима как в области кислых и щелочных значений рН, так и в кислой среде.

КЛЮЧЕВЫЕ СЛОВА: лизоцим; кверцетин; иммобилизация; полимеры; таблеточные смеси.

I. I. Romanovska ${ }^{1}$, S. S. Dekina ${ }^{1}$, O. V. Sevastyanov ${ }^{1}$, Ye. A. Rogozha ${ }^{1}$ O. BOHATSKYI PHYSICO-CHEMICAL INSTITUTE OF NAS OF UKRAINE ${ }^{1}$, ODESA ODESA NATIONAL POLYTECHNIC UNIVERSITY²

\section{TABLETING MIXTURES CONTAINING IMMOBILIZED LYSOZYME AND QUERCETIN: PREPARATION, PROPERTIES}

Introduction. Lysozyme (EC 3.2.1.17), which has antibacterial, anti-inflammatory, immunomodulatory actions is increasingly used in medicine in a different dosage forms: tablets, wound coatings, capsules, gels, etc. Tablet is a convenient dosage form for usage of lysozyme in combination with other biologically active substances. The targeted stabilization of enzyme by immobilization into polymeric matrices determines the relevance of tablet form development of complex compositions of lysozyme and quercetin.

The aim of the study - development of tablet blends of complex preparation of immobilized lysozyme and quercetin, their quantitative determination and the study of the properties of active substances.

Research Methods. Lysozyme activity was determined by bacteriolytic method. The protein content was controlled according to Lowry-Hartree, quercetin - using zirconium chloride.

Results and Discussion. Using the earlier obtained data about the interaction of lysozyme with polymeric supports of different origin and structure, for the development of tableting mixtures with lysozyme and quercetin, as polymeric binders the poly- $N$-vinylpyrrolidone, sodium salt of carboxymethyl cellulose and gelatin were chosen. The comparative analysis of physico-chemical properties of immobilized in polymers lysozyme had shown prospects of gelatin usage as a matrice, which promotes widening of $\mathrm{pH}$-profile of enzyme activity both in areas of acidic and alkaline $\mathrm{pH}$ values, stability in acidic media. For making the lysozyme and quercetin - containing tableting mixtures, the fillers, disintegrants, flavours and wet granulation method were chosen. The total preservation of lysozyme activity and quercetin content in obtained granules was shown.

Conclusions. Tablet mixtures with lysozyme and quercetin with usage of polymeric carriers of different origin and structure were developed. The analysis of biochemical and physico-chemical properties of immobilized lysozyme had shown prospects of gelatin usage as a matrice. Immobilization promotes widening of pH-profile of enzyme activity both in areas of acidic and alkaline $\mathrm{pH}$ values, stability in acidic media.

KEY WORDS: Iysozyme; quercetin; immobilization; polymers; tablet mixtures. 